\title{
GOOD CORPORATE GOVERNANCE AND INTELLECTUAL CAPITAL: EVIDENCE FROM CORPORATE GOVERNANCE PERCEPTION INDEX
}

\author{
Cindy Calista Gunawan ${ }^{1}$ \\ Sekolah Tinggi Ilmu Ekonomi Indonesia \\ Surabaya \\ 30, Menur Pumpungan, Surabaya \\ Indonesia 60118 \\ cindycalistagunawan@gmail.com
}

\author{
Fidiana Fidiana ${ }^{2}$ \\ Sekolah Tinggi Ilmu Ekonomi Indonesia \\ Surabaya \\ 30, Menur Pumpungan, Surabaya \\ Indonesia 60118 \\ fidiana@stiesia.ac.id*
}

\begin{abstract}
This research aimed to examine the effect of financial performance on Good Corporate Governance and intellectual capital to the top ten companies that ranked to the CGPI (Corporate Governance Perception Index). We have 45 samples from 9 companies which included in top ten of the CGPI (Corporate Governance Perception Index) 2013-2017. Based on multiple linear regression, this research have no proved the GCG (Good Corporate Governance) and IC (intellectual capital) as a predictor of financial performance. It means that corporate governance cannot always be used to measure short-term financial performance but is more useful for measuring the company's prosperity in the long run.
\end{abstract}

Keywords: GCG; Intellectual Capital; Institutional Ownership; Managerial Ownership

\begin{abstract}
ABSTRAK
Penelitian ini dimaksudkan untuk menguji kinerja keuangan atas Good Corporate Governance dan modal intelektual terhadap perusahaan dengan memiliki peringkat sepuluh besar pada CGPI (Corporate Governance Perception Index). Berdasar pada metode sampling bersasaran, didapatkan sebanyak 45 sampel dari 9 perusahaan untuk tahun amatan 2013-2017. Teknik uji statistik menggunakan regresi linier berganda. Penelitian ini mengonfirmasi bahwa GCG yang diproksi dengan kepemilikan institusi, kepemilikan manajer, serta modal intelektual bukan merupakan determinan kinerja finansial. Ini berarti bahwa tatakelola perusahaan akan mendatangkan manfaat jangka panjang sehingga tidak selalu dapat digunakan untuk mengukur kinerja keuangan jangka pendek.
\end{abstract}

Kata Kunci : $\quad$ Tatakelola korporasi; Kapital intelektual; Kinerja finansial JEL Classification: G320; G340

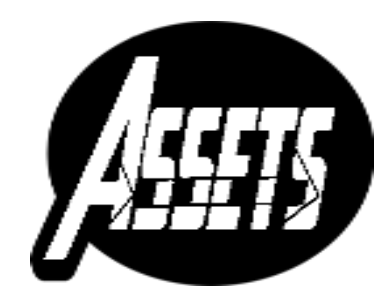

ASSETS

Jurnal Akuntansi dan Pendidikan Vol. 10 No. 1 Page 23 - 32 Madiun, April 2021 p-ISSN: 2302-6251 e-ISSN: 2477-4995

Article History Submitted: October 29, 2019

Accepted: April 22, 2021 


\section{INTRODUCTION}

Company's health can be reflected by financial performance, which is an achievement in a certain period (OECD, 2011). Financial performance attracts investors to invest (Jogiyanto, 2017) especially in companies with good governance, to avoid fiduciary failure risk (Fuenzalida et al., 2013).

Profitability ratios are still often chosen by investors to describe the company's achievement and can estimate the effectiveness of capital (Fidiana et al., 2019; Muryanti \& Subowo, 2017). Previous studies confirmed the GCG (Good Corporate Governance) as a determinant of financial performance (Arora \& Sharma, 2016; Detthamrong et al., 2017; Kusumaningtyas, 2015; Widyaningsih \& Utomo, 2013). GCG implementation improves the climate of stakeholder trust. The higher GCG (Good Corporate Governance) score, the higher of obedience's level so as an investment attraction.

The portion of ownership will determine the scale of minorities as well as a majority ownership in the structure of share ownership in the company (Lozano et al., 2016). Institutional ownership is a tool to reduce agency conflict (Abdallah \& Ismail, 2017; Kremer et al., 2018). Institutional ownership is an effective control mechanism for managers. High external corporate ownership will be as greater protection efforts by corporation investors so that it can withstand opportunistic behavior by managers and can minimize fraud that can be done by management so as to reduce the company value.

Some of previous study indicate that external corporation ownership has a significant impact on financial performance (Aguiar-Diaz et al., 2020). The control function of the institution owner plays an important role in enhancing financial performance. We can conclude that external corporate ownership had a positive impact on financial performance. This study is different from previous GCG research by including only companies with high GCG commitment so they got a CGPI rating that conducted by IICG (The Indonesian Institute for Corporate Governance). The CGPI index is a form of recognition and appreciation to companies that are committed and consistent in implementing GCG in a sustainable manner so that they are entitled to rankings. We used CGPI index as one of indicator for completing prior studies in existing literature on good corporate governance.

Ownership by manager treats managers as shareholders (Ramdani \& van Witteloostuijn, 2012). Managers are not only paid as employees of the company, but functioned as a shareholder (owner) so that it is expected to enhance the company's financial performance effectively (Fajarini \& Firmansyah, 2012). Previous studies have shown the positive effect of ownership by manager on financial performance. The higher the stock owned by the manager, the more the disclosure of valuable information available to the public. It is concluded that ownership by manager had a positive impact on financial performance (Aguiar-Diaz et al., 2020).

The challenges of globalization and the development of information technology and intense competition also underlie changes in the company's financial performance. Companies are forced to change the way they do business from a focus on labor to business based on science and technology (Berzkalne \& Zelgalve, 2014). In this era, capital based on science and technology has shifted conventional capital such as natural resources, financial resources, and other physical assets (Abuzyarova et al., 2019; Lins et al., 2017).

The application of intellectual capital is relatively new in the global environment (Rabaya et al., 2020; Statsenko et al., 2013), not only in Indonesia. Several companies pay more attention on intellectual capital that consist of human resources capital, customer capital, and structural capital (Maharani \& Fuad, 2020). Investment in

http://doi.org/10.25273/jap.v10i1.5326 
intellectual capital aims at efficient management of company resources (Cahya, 2013; Sirojudin \& Nazaruddin, 2014; Utama \& Khafid, 2015). Previous studies have shown results that Intellectual Capital (IC) improves corporate financial performance (Fajarini \& Firmansyah, 2012; Muryanti \& Subowo, 2017; Sunarsih \& Mendra, 2012). It is allegedly that intellectual capital had a positive impact on corporate performance.

This study uses theory of agency, which is all aspects of stakeholders or shareholders in a company that can create potential conflicts of interest (Brigham \& Houston, 2013). Agency theory uses three basic human assumptions, namely humans are self-interested, man power have limited rational power about perceptions in the next future (limited rationality), as well as investor naturally avoid risk (risk-averse) (Eisenhardt, 1989). Agency theory indicates the existence of information asymmetry between stockholder as principals and managers as agents (Jensen \& Meckling, 1976), so it becomes the basis for consideration that company with good CG so as to better financial reputation can be achieved (Detthamrong et al., 2017). The linkage of agency theory with this research is that a good company performance will be obtained because in essence there is the application of good corporate governance as well. This situation is carried out by efforts to encourage a better review of its shareholders (Kusumaningtyas, 2015). In other words, Good CG (Corporate Governance) has capability in reducing agency costs.

\section{METHOD}

This study will use a quantitative approach. We use multiple linear regression to examine the empirical model. The sample of this study was 45 companies (2013-2017) registered in the CGPI (Corporate Governance Perception Index) that conducted by IICG (The Indonesian Institute for Corporate Governance) and have been listing on the ISE (Indonesia Stock Exchange). This observation year 2013-2017 was chosen because of the companies that were ranked in the top ten of CGPI, 8 (eight) of them were banking and financial companies. Meanwhile, the assessment of financial company governance under the Financial Services Authority (OJK) only started in 2013 (Kusjuniati, 2019). Furthermore, the impact of good governance can be monitored for the next 5 years, namely until 2017. IICG is a GCG rating agency for public or listing companies in Indonesia. IICG annually give appreciation and recognition to companies that are committed to implementing GCG and following the CGPI program through the top ten Indonesia Most Trusted Companies Awards. The selected sample is shown in table 1.

Table 1. Research Sample Selection Process

\begin{tabular}{lr}
\multicolumn{1}{c}{ Selection Process } & Total \\
\hline Number of companies participating in CGPI program & 55 \\
Number of companies that did not consistently participate in the 2013-2017 & $(45)$ \\
CGPI program & 10 \\
Number of companies that consistently participate in the 2013-2017 CGPI & \\
program & $(1)$ \\
Companies whose financial statement data cannot be accessed (corrupt): & 9 \\
PT. Asuransi Jasa Indonesia (Persero) & 45 \\
Number of research samples & \\
\hline
\end{tabular}

Source: CGPI Report, 2013-2017 
GCG (Good Corporate Governance) was measured using an IICG assessment score. The CGPI ranking is designed into three criteria based on the level of public trust which could be specified according to the very reliable application score (85.00-100), trusted (70.00-84.99), and quite reliable (55.00-69.99).

Ownership as institutionally can be derived by dividing the ownership of stocks by the institution divided to the total outstanding of stocks. Ownership by manager is specified based on the percentage of share own by management which consists of the board of directors, commissioners, and managers of the 2013-2017 period. Stock own by the managerial is a phenomenon where the manager is also as stockholder (Tjeleni, 2013). The percentage of share ownership divided by the total number of outstanding stocks measures managerial ownership.

Intellectual Capital is specified by the VAICTM (Value Added Intellectual Coefficient), as introduced by Pulic (1998). This model divides intellectual capital into 3 (three) main elements, namely STVA (Value Added Structural Capital), VAHU (Value Added Human Capital), and VACA (Value Added Capital Employed) (Maharani \& Fuad, 2020). ROE is the profitability ratio measured by dividing current year's profit by equity.

Testing is done by $t$ test with the criterion acceptance significance $<0.05$. If the significance value exceeds 0.05 or inappropriate sign, it can be rejected. The F test basically shows whether STVA, VAHU, and VACA are worth testing (Ghozali, 2016). Feasibility model can be concluded by the significance value $>0.05$. Infeasible model is concluded by the significance value $\leq 0.05$.

\section{RESULT AND DISCUSSION}

Descriptive test results as shown in table 2 explain the tiniest ROE of PT Antam of -0.079 and the highest value of 0.268 (BBRI) and the mean of 0.1180 , which means that the company that is a sample of observations of this study is able to achieve a return of 0.12 percent of each unit of equity unit with a fairly low deviation.

Table 2. Devinitive Test

\begin{tabular}{lcrrrr}
\hline & $\mathrm{N}$ & \multicolumn{1}{c}{ Smallest } & \multicolumn{1}{c}{ Largest } & Midpoint & Discrepancy \\
\hline ROE & 45 & -.079 & .268 & .1180 & .07882 \\
CGPI & 45 & 80.100 & 93.860 & 87.3889 & 2.9163 \\
INST & 45 & .000 & 1.000 & .6631 & .1808 \\
MANJ & 45 & .000 & .003 & .0004 & .0008 \\
VAIC & 45 & 4.170 & 42.319 & 11.5351 & 10.3108 \\
Valid N (listwise) & 45 & & & & \\
\hline
\end{tabular}

CGPI values indicate a mean of 87 percent with a $2.9 \%$ deviation. This value illustrates a very reliable score according to the score range 85.00-100 which means the level of public trust in the implementation of CG (corporate governance) is very high. That is, the company really implements CG (corporate governance). In other words, the implementation of governance in companies that follow the ranking of the top ten has been significantly tested. The lowest CGPI score was 80 (PT Timah) and the highest was 93.8 achieved by Bank Mandiri. As a state-owned enterprise, Bank Mandiri is certainly challenged to implement corporate governance as well as possible.

Institutional ownership in the range of 0 to 1 illustrates there are companies whose shares are not owned by other institutions and some are institutionally owned. The average value of 0.66 indicates that in general the ownership of institutions towards company shares is less than 1 . There is no agreement from experts on the 
composition of company ownership that is considered to have a role in making important decisions for the company. However, some studies said that a value more than 1 percent will indicate the role that institutional shareholders can play in contributing to making important decisions (Silalahi, 2016). Values less than 1 in this study reflect the minimal role that institutional shareholders are able to make in making important decisions.

Managerial ownership in the range of 0 indicates the low stock owned by managers. A low level of deviation indicates that there is almost no variation in managerial ownership. Intellectual capital is in the range of 4 (PT. Bank Central Asia) to 42 (PT Aneka Tambang) with an average of $11 \%$. This shows the low investment in intellectual assets. In other words, the companies as the sample of this research were more dominant in investing in non-intellectual resources.

Intellectual capital in this study shown the mean 11.53507 with a standard deviation of 10.310794. In this study, the minimum intellectual capital value of 4,170 is PT Bank Central Asia, while the maximum value of 42,319 is PT Aneka Tambang (Persero) Tbk, which means that the lowest intellectual capital owned by the sample is 4,170 while the highest intellectual capital is 42,319 . The results of multiple linear regression tests are presented in the table 3.

Table 3. Statistical results

\begin{tabular}{|c|c|c|c|c|c|c|c|}
\hline \multirow{2}{*}{\multicolumn{2}{|c|}{ Variabel }} & \multicolumn{2}{|c|}{$\begin{array}{c}\text { Unstandardized } \\
\text { Value }\end{array}$} & \multirow{2}{*}{$\begin{array}{c}\text { Standardized } \\
\text { Value } \\
\text { Beta }\end{array}$} & \multirow{2}{*}{$\mathrm{t}$} & \multirow{2}{*}{ Significance } & \multirow{2}{*}{$\begin{array}{c}\text { Statistics of } \\
\text { Collinearity } \\
\text { Tol. Value }\end{array}$} \\
\hline & & B & $\begin{array}{l}\text { Standard } \\
\text { Error }\end{array}$ & & & & \\
\hline \multirow{5}{*}{1} & (Value) & .492 & .257 & & 1.914 & .063 & \\
\hline & CGPI & .002 & .003 & -.086 & -.745 & .460 & .741 \\
\hline & INST & -.211 & .048 & -.560 & -4.357 & .000 & .597 \\
\hline & MANJ & 8.936 & 10.083 & .104 & .886 & .381 & .716 \\
\hline & VAIC & -.005 & .001 & -.741 & -5.679 & .000 & .579 \\
\hline
\end{tabular}

The Impact of GCG (Good Corporate Governance) on Financial Achievement

Based on table 3, it was known that financial performance could not explained by the GCG (Good Corporate Governance). This means that the implementation of GCG does not affect the welfare of shareholders. This result is contrary to the theory that good governance is very important to be applied to raise company achievement. We can explain that the companies as the sample observation were undoubtedly the top ten companies with the highest index in implementing GCG. This encourages market participants to no longer pay more attention to this aspect because it is definitely the implementation of GCG beyond other companies that do not get the top ten.

Another view explains that ROE (return on equity) is a measure of short-term achievement so it is not aligned with long-term oriented GCG goals. This means that GCG is not quite right if it is related to the target to measure financial performance for only one accounting period (Governance, 2011; OECD, 2011). It results in line with the statement that there is an inverse relationship among the application of GCG (Good Corporate Governance) toward financial achievement (Arora \& Sharma, 2016; Jensen \& Meckling, 1976; Lozano et al., 2016). 


\section{The Influence of Institutional Stocks Own on Financial Achievement}

Statistical test results produce the impact of institutional stock own with financial achievement. Refers to the significance value of institutional ownership in the observed sample which shows a value less than $0,05(0.00)$. The portion of institutional ownership shows the efficiency and effectiveness of the supervisory role that is able to be carried out by the institutional owner to management so that it is able to control the opportunistic behavior of management that can reduce company performance. The greater the share of ownership by corporate investors, the more optimal it will be in supervising managers to improve financial performance and company value (Silalahi, 2016). Thus, corporate ownership is more professional and effective in controlling manager behavior. These results were in line with previous researches which were proved the effect of ownership by the institutional on company achievement (Sakawa \& Watanabel, 2020; Singh \& Kansil, 2018).

Another paradigm states that institutional ownership is an instrument to reduce agency conflicts (Jensen \& Meckling, 1976). Institutional owners will motivate institutions to provide support to management in utilizing resources for the interests of majority shareholders (Sujoko \& Soebiantoro, 2017). The portion of ownership by the institutional illustrates the role of institutional owners in making important decisions including the direction of policies related to financial achievement. Ownership by an institutional is expected to play a large and dominating role in influencing important corporate decisions.

\section{The Influence of Ownership by Managerial on Financial Achievement}

Based on the statistical tests, we found that ownership by the managerial have an impact to the financial achievement. At least share ownership by managers so that the objective of aligning interests as managers and owners who motivate managers to improve company performance becomes effective. The significance of share ownership by managers is effective in encouraging manager behavior to feel that they own the company. Managers are interested in the goal of improving financial performance that benefits the owner (Lozano et al., 2016).

The agency theory paradigm expects managerial ownership to reduce agency problems. When the manager is not given the role of owner, the principal vs. manager conflict is inevitable. Managers tend to prefer to prioritize themselves compared to the achievement of company goals. This means that aligning one's own interests with the interests of investors is very unlikely.

\section{The Impact of Intellectual Capital on Financial Achievement}

Based on the results of statistical tests found that VAICTM (intellectual capital) does affect financial achievement. Refer to stakeholders theory, shows that the company has placed employees as stakeholders. This method is very effective in encouraging employees to optimally empower their intellectual capabilities. In this context, the company means that it has utilized existing intellectual capital to create added value. This also indicates that the companies that are observed in this study have empowered intellectual capital in the company's operational activities so as to motivate employees to contribute to achieving business performance. The recognition of intellectual resources is also an instrument or physical capital to develop harmonious relationships with corporate partners (Baroroh, 2013; Sirapanji \& Hatane, 2015). 
The observation companies in this study were dominated by financial companies (seven banks) and mines (two mining companies). In general, these two types of industries are high-tech industries that are densely packed with physical infrastructure and financial assets. The results of this study has confirmed previous studies about significant results among intellectual capital and financial achievement (Fajarini \& Firmansyah, 2012; Muryanti \& Subowo, 2017; Sunarsih \& Mendra, 2012).

\section{CONCLUSION}

This research aims to empirically examine the impact of GCG (good corporate governance) and VAICTM (intellectual capital) to financial achievement. We were conducted the research at companies that participated in the ranking of the top ten CGPI in 2013-2017. Testing is done by linear regression statistic. Based on the statistical results, we were failed in proving the impact of GCG (good corporate governance) on financial achievement. First, the companies that are observing the data are the top 10 companies implementing GCG. So, there is no doubt that this company must implement GCG to the maximum. In addition, GCG is more oriented to the company's long-term success so that it is unable to provide information on short-term financial performance.

Second, this results failed to prove the relationship of financial achievement from the view of managerial stock own. The low portion of managerial ownership makes control or supervision ineffective so it is less able to play a role in supporting the achievement of financial achievement. Third, The significance of share ownership by managers is effective in encouraging manager behavior to feel that they own the company. Managers are interested in the goal of improving financial performance that benefits the owner. Fourth, the companies that are observed in this study have empowered intellectual capital in the company's operational activities so as to motivate employees to contribute to achieving business performance.

This study has limitations, namely from ten sample observations there is one company whose financial statements are corrupt thereby reducing the number of sample companies. Next, the proxy for financial performance using ROE is not appropriate if it is correlated with GCG. Future research is expected to continue by using other, more representative industries to test intellectual capital.

\section{REFERENCES}

Abdallah, A. A. N., \& Ismail, A. K. (2017). Corporate governance practices, ownership structure, and corporate performance in the GCC countries. Journal of International Financial Markets, Institutions and Money, 46, 98-115. https://doi.org/10.1016/j.intfin.2016.08.004

Abuzyarova, D., Belousova, V., Krayushkina, Z., Lonshchikova, Y., Nikiforova, E., \& Chichkanov, N. (2019). The Role of Human Capital in Science, Technology and Innovation. Foresight and STI Governance, 13(2), 107-119. https://doi.org/10.17323/2500-2597.2019.2.107.119

Aguiar-Diaz, I., Ruiz-Mallorquí, M. V., \& Trujillo, L. (2020). Ownership structure and financial performance of Spanish port service companies. Maritime Economics \& Logistics, 22(4), 674-698. https:/ / doi.org/10.1057/s41278-019-00130-w

Arora, A., \& Sharma, C. (2016). Corporate governance and firm performance in developing countries: evidence from India. Corporate Governance (Bingley), 16(2). https://doi.org/10.1108/CG-01-2016-0018

Baroroh, N. (2013). Analisis Pengaruh Modal Intelektual terhadap Kinerja Keuangan

This work is licensed under a Creative Commons Attribution-ShareAlike 4.0 International License. 
Perusahaan Manufaktur di Indonesia. Jurnal Dinamika Akuntansi, 5(2). https://doi.org/https://doi.org/10.15294/jda.v5i2.2997

Berzkalne, I., \& Zelgalve, E. (2014). Intellectual Capital and Company Value. Procedia Social and Behavioral Sciences. https://doi.org/10.1016/j.sbspro.2013.12.934

Brigham, E. F., \& Houston, J. F. (2013). Manajemen Keuangan. Jakarta: Penerbit Erlangga.

Cahya, H. M. P. (2013). Determinan Luas Pengungkapan Modal Intelektual Pada Perbankan. Accounting Analysis Journal, 2(4). https://doi.org/https://doi.org/10.15294/aaj.v2i4.4174

Detthamrong, U., Chancharat, N., \& Vithessonthi, C. (2017). Corporate governance, capital structure and firm performance: Evidence from Thailand. Research in International Business and Finance. https:// doi.org/10.1016/j.ribaf.2017.07.011

Eisenhardt, K. M. (1989). Agency Theory: An Assessment and Review. The Academy of Management Review, 14(1), 57. https://doi.org/10.2307/258191

Fajarini, I. S., \& Firmansyah, R. (2012). Pengaruh Intellectual Capital Terhadap Kinerja Keuangan Perusahaan (Studi Empiris Perusahaan LQ 45). Jurnal Dinamika Akuntansi, 4(1). https:/ / doi.org/10.15294/jda.v4i1.1954

Fidiana, F., Ngumar, S., \& Retnani, E. D. (2019). Implications of Islamic Governance on Islamic Bank Fraud. Jurnal Reviu Akuntansi Dan Keuangan, 9(2). https://doi.org/https://doi.org/10.22219/jrak.v9i2.58

Fuenzalida, D., Mongrut, S., Arteaga, J. R., \& Erausquin, A. (2013). Good corporate governance: Does it pay in Peru? Journal of Business Research. https://doi.org/10.1016/j.jbusres.2013.01.008

Ghozali, I. (2016). Aplikasi Analisis Multivariete SPSS 25 (Edisi 9). Semarang: Badan Penerbit Universitas Diponegoro.

Governance, C. (2011). The Role of Institutional Investors in Promoting Good Corporate Governance. OECD Report 25 November 2011. https://doi.org/10.1787/9789264128750-en

Jensen, M. C., \& Meckling, W. H. (1976). Theory of the firm: Managerial behavior, agency costs and ownership structure. Journal of Financial Economics, 3(4), 305360. https://doi.org/10.1016/0304-405X(76)90026-X

Jogiyanto, H. (2017). Teori Portofolio dan Analisis Investasi (11th ed.). Yogyakarta: BPFE.

Kremer, T., Bachmann, G., Lutter, M., \& Werder, A. von. (2018). Deutscher Corporate Governance Kodex. Zeitschrift Für Das Gesamte Insolvenzrecht. https://doi.org/10.1515/zinso-2018-0608

Kusjuniati, K. (2019). Dasar Pembentukan Ojk Selaku Pengatur Dan Pengawas Jasa Keuangan Di Indonesia. Jurnal Ilmu Pendidikan Dan Ekonomi, 4(7). https://journal.staidenpasar.ac.id/index.php/wb/article/view/26

Kusumaningtyas, T. K. dan A. (2015). Pengaruh Good Corporate Governance terhadap Nilai Perusahaan yang Terdaftar pada Indeks Sri-Kehati. Jurnal Ilmu Dan Riset Akuntansi, 4(7).

Lins, K. V., Servaes, H., \& Tamayo, A. (2017). Social Capital, Trust, and Firm Performance: The Value of Corporate Social Responsibility during the Financial Crisis. Journal of Finance. https:// doi.org/10.1111/jofi.12505

Lozano, M. B., Martínez, B., \& Pindado, J. (2016). Corporate governance, ownership and firm value: Drivers of ownership as a good corporate governance mechanism. International Business Review, 25(6). https://doi.org/10.1016/j.ibusrev.2016.04.005

Maharani, T., \& Fuad, K. (2020). The effect of human capital, structural capital, 
customer capital, managerial ownership, and leverage toward profitability of company. Journal of Advanced Multidisciplinary Research, 1(1), 46. https://doi.org/10.30659/jamr.1.1.46-62

Muryanti, Y. D., \& Subowo, S. (2017). The Effect of Intelectual Capital Performance, Profitability, Leverage, Managerial Ownership, Institutional Ownership, and Independent Commissioner on The Disclosure of Intelectual Capital. Accounting Analysis Journal, 6(1). https://doi.org/10.15294/aaj.v6i1.11259

OECD. (2011). The Role of Institutional Investors in Promoting Good Corporate Governance. OECD. https://doi.org/10.1787/9789264128750-en

Rabaya, A. J. R., Saleh, N. M., \& Hamzah, N. (2020). Intellectual Capital Performance and Firm Value: The Effect of MFRS 139. The South East Asian Journal of Management, 14(1). https:/ / doi.org/10.21002/ seam.v14i1.11851

Ramdani, D., \& van Witteloostuijn, A. (2012). The Shareholder-Manager Relationship and Its Impact on the Likelihood of Firm Bribery. Journal of Business Ethics, 108(4), 495-507. https://doi.org/10.1007/s10551-011-1105-5

Sakawa, H., \& Watanabel, N. (2020). Institutional Ownership and Firm Performance under Stakeholder-Oriented Corporate Governance. Sustainability, 12(3), 1021. https://doi.org/10.3390/su12031021

Silalahi, D. (2016). Pengaruh Kepemilikan Institusional terhadap Karakteristik Pasar Saham di Bursa Efek Indonesia. Jurnal Manajemen Dan Bisnis, 16(2), 1-12. http://www.ejournal.ust.ac.id/index.php/JIMB_ekonomi/article/view/128

Singh, A., \& Kansil, R. (2018). Institutional ownership and firm performance: evidence from Indian panel data. International Journal of Business and Emerging Markets, 10(3), 250. https://doi.org/10.1504/IJBEM.2018.10013055

Sirapanji, O., \& Hatane, E. (2015). Pengaruh Value Added Intellectual Capital Terhadap Kinerja Keuangan dan Nilai Pasar Jasa Yang Terdaftar Di Bursa Efek Indonesia Tahun 2008 - 2013. Business Accounting Review. https://doi.org/10.1111/j.0022-3646.1985.00323.x

Sirojudin, G. A., \& Nazaruddin, I. (2014). Pengaruh Modal Intelektual dan Pengungkapannya Terhadap Nilai dan Kinerja Perusahaan. Jurnal Akuntansi Dan Keuangan. https://doi.org/10.18196/JAI-2015.0035

Statsenko, L., Bozhko, L., Prause, G., \& Ireland, V. (2013). Critical issues of intellectual capital theory in transitional countries. Global Business Perspectives, 1(4), 515537. https://doi.org/10.1007/s40196-013-0030-7

Sujoko, S., \& Soebiantoro, U. (2017). Pengaruh Struktur Kepemilikan, Strategi Diversifikasi, Leverage, Faktor Intern dan Faktor Ekstern terhadap Nilai Perusahaan (Studi Empirik Pada Perusahaan Manufaktur Dan Non Manufaktur Di Bursa Efek Jakarta). EKUITAS (Jurnal Ekonomi Dan Keuangan), 11(2), 236. https://doi.org/10.24034/j25485024.y2007.v11.i2.2236

Sunarsih, N. M., \& Mendra, N. P. Y. (2012). Pengaruh Modal Intelektual Terhadap Nilai Perusahaan Dengan Kinerja Keuangan Sebagai Variabel Intervening Pada Perusahaan Yang Terdaftar Di Bursa Efek Indonesia. SNA XV Banjarmasin.

Tjeleni, I. E. (2013). Kepemilikan Manajerial Dan Institusional Pengaruhnya Terhadap Kebijakan Hutang Pada Perusahaan Manufaktur Di Bursa Efek Indonesia. Jurnal Emba, 1(3). https://doi.org/https://doi.org/10.35794/emba.v1i3.1949

Utama, P., \& Khafid, M. (2015). Faktor-Faktor Yang Mempengaruhi Luas Pengungkapan Modal Intelektual Pada Perusahaan Perbankan di BEI. Accounting Analysis Journal, 4(2).

Widyaningsih, F., \& Utomo, S. W. (2013). Pengaruh Good Corporate Governance Dan

This work is licensed under a Creative Commons Attribution-ShareAlike 4.0 International License. 
Struktur Kepemilikan Terhadap Kinerja Perusahaan (Studi Empiris Pada Perusahaan Manufaktur Yang Terdaftar Di Bei Tahun 2010-2011). Assets: Jurnal Akuntansi Dan Pendidikan, 2(2), 98. https:/ / doi.org/10.25273/jap.v2i2.1202. 